\title{
2016 APSA Committees
}

\section{ACADEMIC AND PROFESSIONAL DEVELOPMENT COMMITTEES}

\section{Committee on Departmental Services}

The Committee on Departmental Services advises on publications and other services for members of the association's Departmental Services Program.

Term expiring August 31, 2016

Priscilla Regan, George Mason University, Chair

Jarvis Hall, North Carolina Central University

Term expiring August 31, 2017

Tony Messina, Trinity College (Hartford, Connecticut)

KC Morrison, Mississippi State

Term expiring August 31, 2018

Thomas Keck, Syracuse University

George Lovell, University of Washington

\section{Committee on Teaching and Learning}

The Committee on Teaching and Learning develops and promotes activities within APSA and the political science community regarding political science and the practices and policies of higher education, including undergraduate, graduate, professional, and life-long education. The committee addresses issues of course and curriculum preparation and assessment, the professional development of college and graduate teaching, pedagogies and strategies of teaching and learning for the diversity of our students and program missions, instructional technologies and other resources, and higher education policy. It encourages studies in these areas, promotes supportive projects and materials development, and advises the APSA Council. The committee also advises the APSA Council on the practices and policy for the annual APSA Teaching and Learning Conference.

Term expiring August 31, 2016

Tressa E. Tabares, American River College

Sherri L. Wallace, University of Louisville Term expiring August 31, 2017

Stephen Meinhold, University of North Carolina, Wilmington, Chair

Desiree Pedescleaux, Spelman College

Term expiring August 31, 2018

Lee Trepanier, Saginaw Valley State University

Alison McCartney, Towson University

\section{Teaching and Learning Conference Program Committee}

Dick Simpson, University of Illinois at Chicago

Chad Raymond, Salve Regina University

Sara Moats, Florida International University

Audrey Haynes, University of Georgia

Chera LaForge, Indiana University East

\section{APSA Ad Hoc Working Group on \\ Assessment}

Lawrence Baum, The Ohio State University

Michelle Deardorff, Jackson State University

Lynne Ford, College of Charleston

John Ishiyama, University of North Texas

Joseph P. McCormick II, Penn State University, York

Candace Young, Truman State University, Chair

\section{Committee on Civic Education and Engagement}

The APSA Committee on Civic Education and Engagement focuses on the contributions that higher education, and political sciences in higher education institutions, are making or could make to enhancing the quantity and quality of civic engagement among young Americans.

Term expiring August 31, 2016 Kristin Goss, Duke University, Chair Brian M. Harward, Allegheny College

Term expiring August 31, 2017

Walter Wilson, University of Texas, San Antonio

\section{ACTIVE COMMITTEES}

\section{Centennial Center Advisory Board}

The Centennial Center Advisory Board oversees practices of the Centennial Center for Political Science and Public Affairs, raises funds for center activities, and makes final decisions on awarding of Centennial Center scholarships and grants.

Term expiring August 31, 2016

Andrea Louise Campbell, Massachusetts Institute of Technology

Gerald Gamm, University of Rochester

Sharon Ann Navarro, University of Texas at San Antonio

Term expiring August 31, 2017
Phil Keefer, Inter-American Development Bank

Term expiring August 31, 2018

Costas Panagopoulos, Fordham University

Toni Michelle Travis, George Mason University

\section{International Political Science}

The Committee on International Political Science Recommends policy to the APSA council with regard to international membership issues, oversees relationships with other national and international political science associations, and supports the inclusiveness of the APSA's work and activities in ways that transcend national boundaries.

Term expiring August 31, 2016

Yun-han Chu, Academia Sinica

Mark Tessler, University of Michigan

Term expiring August 31, 2017

Hilde Coffe, Victoria University of Wellington, Chair

Laura Morales, University of Leicester

Term expiring August 31, 2018

Karen Anderson, University of Southampton

Todd Eisenstadt, American University

\section{ANNUAL MEETING COMMITTEES}

\section{Annual Meeting Committee}

The committee on the annual meeting is designed to oversee the practices and policies of the APSA Annual Meeting.

Term expiring August 31, 2016

Stacia L. Haynie, Louisiana State University

Tyson D. King-Meadows, University of Maryland, Baltimore County

Term expiring August 31, 2017

Rick Valelly, Swarthmore College, Chair

\section{Committee on Siting and Engagement}

This committee addresses the application of APSA siting policy for the APSA Annual Meeting, the Teaching and Learning Conference, and other major APSA meetings, and plans for a program of public engagement in the community once a site has been selected.

Term expiring August 31, 2016

Robin A. Kolodny, Temple University

Maruice Mangum, Texas Southern University 
Anne Norton, University of Pennsylvania

Term expiring August 31, 2017

Melissa Michelson, Menlo College

Justin Vaughn, Boise State University

David Wilson, University of Delaware

Term expiring August 31, 2018

Ben McKean, Ohio State University

Rachael Cobb, Suffolk University, Chair

Theodore J. Davis, Jr., University of Delaware

\section{COUNCIL COMMITTEES}

\section{Administrative Committee}

The Administrative Committee consists of the president, president-elect, treasurer, and four other council members whose main duties include preparing agendas for council meetings and annual business meetings and acting on behalf of the council to dispose of policy issues deemed of insufficient weight to require decisions by the council.

Term expiring August 31, 2016

Jennifer Hochschild, Harvard University

David Lake, University of California, San Diego

Taeku Lee, University of California, Berkeley

Maria Escobar-Lemmon, Texas A\&M University

Amaney Jamal, Princeton University

Martha Finnemore, George Washington University

Bo Rothstein, University of Gothenburg

Suzanne Mettler, Cornell University

\section{Audit Committee}

The Audit Committee supervises the conduct of APSA's audit and oversees that adequate internal controls exist for the Association's accounting and finance. The audit committee is comprised of three members: two from the council and one from the trust and development board of trustees. Members and the chair are named by the president with the advice and consent of the council.

Term expiring August 31, 2016

David Stasavage, New York University

Caroline Tolbert, University of Iowa

Charles Stewart, Massachusetts Institute of Technology

\section{Committee on Elections}

The Committee on Elections supervises the conduct of APSA's elections. Three members are appointed after the election from among newly elected and continuing council members.

Term expiring August 31, 2016
Byron D'Andra Orey, Jackson State University

Mark Warren, University of British

Columbia

David Lublin, American University

\section{Finance Committee}

The Finance Committee examines and interprets the trends in APSA finances and oversees patterns of revenues and expenditures relative to budget.

Term expiring August 31, 2016

Taeku Lee, University of California, Berkeley, Chair

Frank Baumgartner, University of North Carolina at Chapel Hill

Michelle Deardorff, University of Tennessee at Chattanooga

\section{Committee on Rules}

The Committee on Rules reviews APSA's by-laws and rules of procedure for governing the conduct of the annual business meeting and proposes revisions as they are deemed necessary.

Term expiring August 31, 2016

Cameron Thies, Arizona State University

James Mahoney, Northwestern University

\section{GOVERNANCE COMMITTEES}

\section{Governance Reform Ad Hoc Committee}

David A. Lake, University of California, San Diego, Chair

Jeffrey Berry, Tufts University

Terri Givens, Menlo College

Kerstin Hamann, University of Central

Florida

Jonathan Koppell, Arizona State

University

Ashley Leeds, Rice University

Joanne Miller, University of Minnesota

Jeffrey Segal, Stony Brook University

Dara Strolovitch, Princeton University

\section{Development Committee}

The Development Committee proposes development goals and policies to the Council, oversees their eventual implementation, and has oversight of APSA Awards.

Term expiring August 31, 2016 Joanne Gowa, Princeton University Matthew C. Moen, University of South Dakota

\section{Professional Ethics, Rights, and Freedoms Committee}

The responsibility of the Committee on Professional Ethics, Rights, and Freedoms is to protect the rights of political scientists and ensure that the ethical policies of the Association are followed.

Term expiring August 31, 2016

Scott W. Desposato, University of California, San Diego

Term expiring August 31, 2017

David Campbell, University of Notre Dame

Susanna Wing, Haverford College

Term expiring August 31, 2018

Virginia Sapiro, Boston University, Chair

Michael Fortner, CUNY Graduate Center

Samantha Frost, University of Illinois, Urbana-Champaign

Noah Pickus, Duke University

\section{Nominating Committee}

Term expiring August 31, 2016

Sheri Berman, Barnard College-Columbia

University, Chair

Luis Fraga, University of Notre Dame

Sara Mitchell, University of Iowa

Term expiring August 31, 2017

Fred Harris, Columbia University

Tarek Masoud, Harvard University

Chris Gelpi, Ohio State University

\section{Organized Sections Committee}

Term expiring August 31, 2016

Carol S. Weissert, Florida State University, Chair

Holly Brasher, University of Alabama, Birmingham

Term expiring August 31, 2017

Juan Carlos Huerta, Texas A\&M

University, Corpus Christi

Lori Weber, California State University, Chico

Term expiring August 31, 2018

Carol Mershon, University of Virginia

Willem Maas, York University

\section{PUBLICATIONS COMMITTEES}

\section{Committee on Publications}

The Committee on Publications oversees and coordinates existing APSA publications, explores possible relationships with political science journals not sponsored by APSA, and, when appropriate, develops proposals for new publications.

Term expiring August 31, 2016

Karen Beckwith, Case Western Reserve University

John Geer, Vanderbilt University

Term expiring August 31, 2017

Alan Ware, Oxford University, London 


\section{Publications Planning Ad Hoc}

\section{Committee}

The charge to the Publications Planning Committee is to look broadly at the needs, opportunities and issues for the future of scholarly publications and communications of the association, and to make recommendations for new initiatives or changes in approach. In conducting its analysis, the committee considers the evolving technologies and formats for electronic media and open access, the formats and editorial arrangements for the existing publications and communications of the association, including standing journals, eNewsletters, organized section journals and newsletters, ideas for eJournals, and the future prospects for the editorial arrangement and structure for PS: Political Science and Politics. The committee also considers how the APSA scholarly journals are balanced regarding the needs of scholarly production, research audiences and teaching, junior faculty and emerging scholars, association members, press and policy makers, and the attentive public.

Term expiring September 30, 2018:

Jennifer L. Hochschild, Harvard University, Chair

Larry M. Bartels, Vanderbilt University

Simone Chambers, University of Toronto

Derrick L. Cogburn, American University

Eric Crahan, Oxford University Press

Yoshiko M. Herrera, University of Wisconsin, Madison

Macartan Humphreys, Columbia University

Karen M. Kedrowski, Winthrop University

Marc Lynch, George Washington University

Rahsaan Maxwell, University of Massachusetts, Amherst

Ricardo Ramirez, University of Notre Dame

Kaare Strom, University of California, San Diego

\section{Ex-Officio Members}

Phillip Ardoin, Appalachian State University, Editor, PS: Political Science and Politics

Paul Gronke, Reed College, Editor, PS: Political Science and Politics

Jeffrey C. Isaac, Indiana University, Editor, Perspectives on Politics

John Ishiyama, University of North Texas, Editor, APSR

\section{STATUS COMMITTEES}

\section{Status of Asian Americans in the Profession}

The Committee on the Status of Asian Pacific Americans in the Profession develops and promotes activities concerning the professional development of Asian American and Pacific Islander political scientists.

Term expiring August 31, 2016

Natalie Masuoka, Tufts University

Karthick Ramakrishnan, University of California, Riverside

Term expiring September 4, 2017

Naomi Murakawa, Princeton University

Rebecca Deen, University of Texas, Arlington, Chair

Term expiring August 31, 2018:

Okiyoshi (Oki) Takeda, Aoyama Gakuin University

Julie Merseth, Northwestern University

\section{Status of Blacks in the Profession}

The Committee on the Status of Blacks in the Profession develops and promotes activities concerning the professional development of African Americans within the discipline.

Term expiring August 31, 2016

Shayla C. Nunnally, University of Connecticut

James Lance Taylor, University of San Francisco, Chair

Term expiring September 4, 2017

Michael Fauntroy, Howard University

Atiya Stokes, Bucknell University

Term expiring August 31, 2018

Clarissa Hayward, Washington University

in St. Louis

Porsha Cropper, Abt Associates

\section{Status of Latinos y Latinas in the Profession}

The Committee on the Status of Latinos $y$ Latinas in the Profession develops and promotes activities concerning the professional development of Latino scholars within the discipline.

Term expiring August 31, 2016

Christina Elizabeth Bejarano, University of Kansas

Maria C.Escobar-Lemmon, Texas A\&M University

Term expiring September 4, 2017

Maria Chavez, Pacific Lutheran University

Eric Juenke-Gonzalez, Michigan State

Term expiring August 31, 2018

Linda Mancillas, Georgia Gwinnett College, Chair
Stephen Nuno, Northern Arizona University

\section{LGBT Status in the Profession}

This committee assesses the status of lesbian, gay, bisexual, and transgendered (LGBT) scholars in the profession, advances the research on LGBT issues, develops curriculum materials, and works to ensure tolerance toward LGBT political scientists.

Term expiring August 31, 2016

Patrick J. Egan, New York University

Mary Caprioli, University of MinnesotaDuluth

Term expiring September 4, 2017

Shawn Schulenberg, Marshall University Ellen Andersen, University of Vermont Term expiring August 31, 2018 Jami Taylor, University of Toledo, Chair Rick Valelly, Swarthmore College

\section{Committee on the Status of Women in the Profession}

The Committee on the Status of Women in the Profession monitors and reports on the status of women in the profession, advances research on women and on issues of concern to women, develops and assesses curriculum materials, and works to ensure fair and equal treatment of women in the profession.

Term expiring August 31, 2016

Stefanie Chambers, Trinity College

Leela Fernandes, University of Michigan

Term expiring September 4, 2017

Nadia Brown, Purdue University

Frances Rosenbluth, Yale University, Chair

Term expiring August 31, 2018

Denise Walsh, University of Virginia

Amy Atchison, Valparaiso University

\section{Workable Solutions to Advancing Women in the Profession Ad Hoc Committee}

The goal of the committee is not to collect more data about the position of women in political science but to begin the process of ensuring that such focused and systematic policies are put in place. The committee will be concerned with actual and potential solutions to the problem; it will identify and bring together promising policies that already exist in some universities with suggestions for new policies that offer workable solutions. The package of policies will then be publicized as "best practice" throughout our discipline so that everyone is aware of what can and should be done. 
The APSA has no enforcement powers, but it does have the power of publicity and the support of women in our profession.

Kristen Monroe, University of California,

Irvine, Chair

Martha Ackelsberg, Smith College

Angela Lewis, University of Alabama,

Birmingham

Donna Shalala, University of Miami

Michele Swers, Georgetown University

\section{AWARD COMMITTEES}

\section{John Gaus Award Committee}

Lael Keiser, University of Missouri,

Columbia, Chair

Frances Berry, Florida State University

Dan Carpenter, Harvard University

\section{Frank J. Goodnow Award Committee} Anne Schneider, Arizona State Unviersity, Chair

Tom Remington, Emory University Richard Johnston, University of British Columbia

\section{Hubert H. Humphrey Award \\ Committee}

Raphael Sonenshein, California State

University, Los Angeles, Chair

Les Lenkowsky, Indiana University

Tony King, University of Essex

\section{Carey McWilliams Award Committee}

Steve Livingston, George Washington

University, Chair

Josh Tucker, New York University

Andrew Chadwick, Royal Holloway,

University of London

\section{Distinguished Teaching Award \\ Committee}

Sherri Wallace, University of Louisville,

Chair

Jacqui Briggs, University of Lincoln

Richard Holtzman, Bryant University

\section{Ithiel de Sola Pool Award Committee}

Danielle Vinson, Furman University, Chair

Mat Baum, Harvard University

Andy Gelman, Columbia University
DISSERTATION AWARDS

Term Expiring August 31, 2016

\section{E.E. Schattschneider Award Committee}

Lina Newton, Hunter College, Chair

Kent Portney, Texas A\&M University

Dan Hopkins, Georgetown University

Edward S. Corwin Award Committee

Amy Steigerwalt, Georgia State

University, Chair

Anthony Lang, University of St. Andrews

Gretchen Helmke, University of Rochester

\section{Gabriel A. Almond Award Committee} Arthur Spirling, New York University, Chair

Marc Howard, Georgetown University

Lisa Blaydes, Stanford University

Howard D. Lasswell Award Committee

Jennifer Clark,University of Houston,

Chair

Chris Koski, Reed College

Christian Breunig, University of Konstanz

\section{Helen Dwight Reid Award Committee}

Kristian Skrede Gleditsch, University of

Essex, Chair

Susan Hyde, Yale University

Paul Poast, University of Chicago

\section{Leo Strauss Award Committee}

Jill Hargis, California State Polytechnic University, Pomona, Chair

Leigh Jenco, London School of Economics Lars Toender, University of Copenhagen

\section{Leonard D. White Award Committee} Rosemary O'Leary, University of Kansas, Chair

Susan Miller, University of South Carolina

Sergio Fernandez, Indiana University

\section{William Anderson Award Committee}

Liesbet Hooghe, University of North

Carolina/University of Amsterdam, Chair Yoshiko Herrera, University of Wisconsin Shanna Rose, Claremont McKenna College

\section{BOOK AWARDS}

Ralph J. Bunche Award Committee Christina Greer, Fordham University, Chair

Kanchan Chandra, New York University Marc Helbing, WZB Berlin Social Science Center

\section{Gladys M. Kammerer Award}

Committee

Eleanor Powell, University of Wisconsin, Chair

Sara Anzia, University of California, Berkeley

Andrew Rudalevige, Bowdoin College

Victoria Schuck Award Committee

Jill Vickers, Carleton University, Chair

Shauna Shames, Rutgers University at Camden

Fiona Mackay, University of Edinburgh

\section{Woodrow Wilson Foundation Award Committee}

John Mollenkopf, City University of New York, Chair

Ashu Varshney, Brown University James Robinson, University of Chicago

\section{PAPER AND ARTICLE AWARDS}

\section{Heinz Eulau Award Committee}

Chair: Aseem Prakash, University of Washington

American Political Science Review Michelle Dion, McMaster University Macartan Humphreys, Columbia University

Perspectives on Politics

Martin Gilens, Princeton University Virginie Guiraudon, Sciences Po

\section{Franklin L. Burdette Award}

\section{Committee}

Carol Nackenoff, Swarthmore College, Chair

Jake Bowers, University of Illinois Jonas Pontusson, University of Geneva 